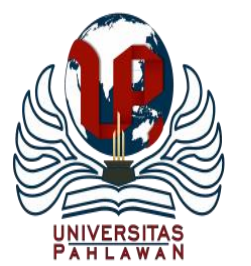

Jurnal Abdidas Volume 2 Nomor 4 Tahun 2021 Halaman 752-757

JURNAL ABDIDAS

http://abdidas.org/index.php/abdidas

\title{
Upaya Pengendalian Kecemasan Masyarakat dengan Tetap Positif dan Produktif di Masa Pandemi Covid-19
}

\author{
Yulifah Salistia Budi \\ Keperawatan, Sekolah Tinggi Ilmu Kesehatan Banyuwangi, Indonesia \\ E-mail : yulifahsalistia@gmail.com
}

\begin{abstract}
Abstrak
Dampak pandemi Covid-19 terjadi mulai segi ekonomi, SDM, pendidikan, pariwisata dan sebagainya dimana hal ini menimbulkan kecemasan pada sebagian besar masyarakat. Kecemasan muncul sebagai akibat dari perasaan yang tidak menyenangkan akibat bahaya penyakit dan penularannya sehingga masyarakat diharuskan untuk melakukan aktifitas di rumah saja "stay at home". Upaya untuk mengendalikan kecemasan yaitu dengan melakukan strategi koping, salah satunya dengan tetap berpikir positif dan produktif selama masa pandemi Covid-19. Kegiatan pengabdian masyarakat ini bertujuan untuk meningkatkan pengetahuan masyarakat tentang pandemi Covid-19 khususnya di masyarakat Banyuwangi, dan meningkatkan pengetahuan masyarakat tentang upaya pengendalian kecemasan akibat pandemi Covid-19. Kegiatan ini menggunakan metode edukasi kesehatan melalui live streaming dan siaran radio dengan sasaran seluruh masyarakat Kecamatan Banyuwangi. Hasil kegiatan ini yaitu peningkatan pemahaman masyarakat terkait dengan pandemi Covid-19, untuk tetap berpikir positif dan produktif meskipun dirumah saja sebagai upaya pengendalian kecemasan yang dialami oleh masyarakat serta peningkatan motivasi masyarakat untuk tetap bersyukur, lebih mendekatkan diri kepada Tuhan-nya. Covid-19 memberikan dampak dari segala segi kehidupan termasuk dalam hal kesehatan jiwa yaitu kecemasan yang dialami masyarakat. Dengan upaya ini dinilai dapat mengendalikan kecemasan masyarakat pada umumnya dan Banyuwangi khususnya.
\end{abstract}

Kata kunci : Covid-19, kecemasan, positif dan produktif

\section{Abstract}

The impact of the COVID-19 pandemic has occurred in terms of the economy, human resources, education, tourism and so on where this has caused anxiety for most people. Anxiety as a result of unpleasant feelings due to the dangers of disease and its transmission so that people are required to carry out activities at home "stay at home". Efforts to control anxiety are through coping strategies, one of which is by staying positive and productive during the COVID-19 pandemic. This community service activity aims to increase public knowledge about the COVID-19 pandemic, especially in the Banyuwangi people, and increase public knowledge about efforts to control anxiety due to the COVID-19 pandemic. This activity uses health education methods through live streaming and radio broadcasts targeting the entire community of Banyuwangi District. The results of this activity are increasing public knowledge related to the covid-19 pandemic, to keep thinking positively and productively even at home as an effort to control anxiety experienced by the community as well as increasing people's motivation to remain grateful, closer to God. Covid-19 has an impact on all aspects of life, including mental health, namely the anxiety experienced by the community. With this effort, it is considered to be able to control anxiety in general and especially the Banyuwangi people.

Keywords: anxiety, covid-19, positive and productive

Copyright (c) 2021 Yulifah Salistia Budi

$\triangle$ Corresponding author

Address : Jalan Letkol Istiqlah 109, Banyuwangi, Jawa Timur

Email : yulifahsalistia@gmail.com

DOI : https://doi.org/10.31004/abdidas.v2i4.360

ISSN 2721- 9224 (Media Cetak)

ISSN 2721- 9216 (Media Online) 
753 Upaya Pengendalian Kecemasan Masyarakat dengan Tetap Positif dan Produktif di Masa Pandemi Covid-19 - Yulifah Salistia Budi

DOI: https://doi.org/10.31004/abdidas.v2i4.360

\section{PENDAHULUAN}

Coronavirus Disease-19 atau Covid-19 disebabkan oleh sindrom pernapasan akut Coronavirus 2 (severe acute respiratory syndrome coronavirus 2 atau SARS-CoV-2). Penyakit ini termasuk kedalam penyakit yang mudah menular melalui droplet orang yang batuk, udara dan juga permukaan yang telah terkontaminasi virus Corona (Kementrian Kesehatan Republik Indonesia, 2020). Pada akhir Januari 2020, saat kasus positif Covid-19 belum dinyatakan terdeteksi di Indonesia sementara beberapa negara tetangga seperti Singapura, Malaysia. Thailand dan Australia telah mengumumkan kasus terinfeksinya virus tersebut. Per tanggal 2 Maret 2020 nama Indonesia masuk ke dalam negara yang terjangkit virus corona dan Presiden Joko Widodo mengumumkan virus corona Wuhan menjangkiti dua warga Indonesia, tepatnya di kota Depok, Jawa Barat.

Menteri Kesehatan Terawan Agus Putranto, memberikan tips untuk mencegah virus corona yaitu dengan berpikir positif dan menjaga imunitas tubuh (Pratama, 2020). Kini, virus tersebut telah memasuki negara Indonesia bahkan merambah ke Kabupaten Banyuwangi khususnya sejak diumumkan pada 29 Maret 2020 oleh Bupati Banyuwangi kala itu. Hal tersebut berdampak pada berbagai sektor mulai ekonomi, SDM, pendidikan, pariwisata dan sebagainya dimana hal ini menimbulkan kecemasan pada sebagian besar masyarakat.

Kecemasan merupakan perwujudan emosi yang terjadi karena seseorang mengalami tekanan perasaan dan batin, sehingga untuk merasa aman maka penyelesaian yang baik oleh individu dapat menyelesaikan kondisi tersebut. Namun, pada kenyataannya tidak semua masalah dapat diselesaikan dengan baik oleh individu, bahkan ada yang cenderung dihindari, dimana hal tersebut dapat menimbulkan perasaan yang tidak menyenangkan (Supriyantini, 2010 dalam Salistia Budi, 2021). Pada kondisi saat ini, kecemasan muncul akibat bahaya penyakit dan penularannya sehingga masyarakat diharuskan untuk melakukan aktifitas di rumah saja "stay at home". Pasien Covid-19 rentan mengalami gangguan psikologis berupa kecemasan. Konsekuensi psikologis ini menyerang karena pasien memiliki kecemasan berlebih terutama kondisi fisik dan pola interaksi yang serba dibatasi dalam rangka menekan persebaran virus (Jannah et al., 2020). Gangguan kecemasan masyarakat Indonesia menunjukkan bahwa terdapat empat variabel yang mempengaruhi tingkat gangguan kecemasan selama pandemi yaitu usia, gender, pendidikan, dan pekerjaan (Megatsari et al., 2020). Usaha untuk mengendalikan kecemasan salah satunya adalah menggunakan strategi koping.

Strategi koping merupakan cara atau metode yang dilakukan seseorang untuk mengatasi dan mengendalikan situasi yang dialami dan dipandang sebagai hambatan (Kertamuda \& Herdiansyah, 2009).

Strategi Koping memoderasi hubungan secara positif, sehingga hubungan antara fleksibilitas kerja dan produktivitas kerja semakin meningkat ketika karyawan menerapkan mekanisme koping yang berfokus pada masalah untuk mengendalikan stresor dan menjaga produktivitas kerja mereka selama pandemi Covid- 
754 Upaya Pengendalian Kecemasan Masyarakat dengan Tetap Positif dan Produktif di Masa Pandemi Covid-19 - Yulifah Salistia Budi

DOI: https://doi.org/10.31004/abdidas.v2i4.360

19 (Ishak \& Mangundjaya, 2020). Bentuk koping yang dapat dilakukan oleh individu yaitu dengan berpikir positif dan berperilaku produktif sebagai bentuk dari strategi koping berpusat pada tugas.

Kampanye berpikir positif bukan hal yang salah. Hanya saja berdasarkan fakta empiris, ada batasan yang perlu dipahami oleh masyarakat bahwa berpikir positif akan berdampak positif pada jenis stresor tertentu. Oleh karena itu, perlu sosialisasi dan edukasi kepada masyarakat terkait hal ini agar tidak menimbulkan bias optimisme yang justru membahayakan nyawa mereka sendiri akibat mengabaikan anjuran para ahli kesehatan (Rohmatussyifa \& Sa'id, 2020).

Menurut seorang dokter Spesialis Kesehatan Jiwa (Kusumastiwi, 2020) mengungkapkan bahwa ada beberapa kiat dalam berpikir positif yaitu [1] Here and Now, yang dimaksud disini adalah individu cukup memikirkan yang saat ini dan ada di dekatnya. Dengan kata lain, kerjakan yang prioritas dan terdekat. [2] Membuat aturan dalam berpikir. Saat ini banyak diantara kita yang berusaha mencari pengetahuan mengenai Covid-19 sebagai usaha untuk mengatasi problem (antisipasi), namun beberapa hal harus kita perhatikan : sumber, jenis informasi, kapan dan seberapa lama kita mendapatkan informasi tersebut. [3] Bersyukur. Kiat ini merupakan gambaran hubungan setiap individu dengan Tuhan nya. [4] Iam Ok, You are okkay. Pentingnya kita meyakini bahwa setiap orang sedang berusaha menjalankan perannya semaksimal mungkin dan kita harus berusaha memahami cara pandang orang lain sehingga kita bisa merasa nyaman dengan kondisi yang ada. Selanjutnya dari kiat tersebut beliau turunkan ke dalam perilaku yang produktif yaitu [1] membuat list kegiatan yang terstruktur, [2] me time, [3] berolah raga, [4] menjalin komunikasi, [5] upgrade diri, serta [6] berkontribusi untuk orang lain.

Dari kondisi dan situasi pandemi ini, maka pentingnya dilakukan pengendalian terhadap kecemasan yang dialami oleh masyarakat untuk tetap produktif meskipun di rumah saja, hal ini bertujuan supaya mereka dapat beradaptasi dengan kondisi normal baru akibat dari pandemi ini. Kondisi kecemasan apabila tidak dikendalikan dapat memunculkan masalah kesehatan jiwa, karena dampak dari pandemi ini bukan hanya secara ekonomi tetapi stres, kecemasan dan tekanan mental juga merupakan dampak dari pandemi Covid-19. Hal ini dilihat dari data Kemeskes selama pandemi Covid-19 hingga Juni 2020 tercatat sebanyak 277.000 kasus kesehatan jiwa di Indonesia, dan jumlah kasus ini telah mengalami peningkatan dibandingkan tahun 2019 yang hanya 197.000 kasus.

Tujuan dari pengabdian masyarakat ini adalah untuk [1] meningkatkan pengetahuan masyarakat tentang pandemi Covid-19 khususnya di masyarakat Banyuwangi, dan [2] peningkatan pengetahuan masyarakat tentang upaya pengendalian kecemasan akibat pandemi Covid-19 pada masyarakat Banyuwangi.

\section{METODE}

Kegiatan pengabdian masyarakat ini dilakukan dengan metode pemberian edukasi kepada masyarakat tentang Covid-19 dan kiat pengendalian kecemasan untuk tetap berpikir 
positif dan produktif di masa pandemi pada masyarakat sebagai akibat regulasi pemerintah untuk stay at home. Pelaksanaan kegiatan ini dilakukan selama satu hari yaitu pada tanggal 29 April 2020 yang dilakukan melalui siaran radio 101,5 VIS FM dan live streaming melalui zoom yang dapat didengar dan diakses oleh masyarakat Kecamatan Banyuwangi. Kegiatan ini juga melibatkan narasumber dari sisi agama Islam karena tema ini juga diintegrasikan dengan tema bulan Ramadhan di masa pandemi Covid-19.

Pada akhir kegiatan ini terdapat sesi tanya jawab antara narasumber dengan pendengar/audience, yang bertujuan untuk mengevaluasi tingkat pemahaman audience terhadap kiat pengendalian kecemasan dengan cara berpikir positif yang diintegrasikan dengan nilai Islami serta perilaku-perilaku produktif selama masa pandemi Covid-19 yang dipandu oleh penyiar radio yang bertugas sebagai pemandu acara.

\section{HASIL DAN PEMBAHASAN}

Kegiatan pengabdian masyarakat yang dilakukan melalui siaran radio ini memberikan pengetahuan kepada masyarakat tentang pandemi covid-19, upaya pengendalian kecemasan melalui berpikif positif dan produktif selama di rumah saja serta memberikan kualitas syukur dan beribadah individu terhadap Tuhan-nya.

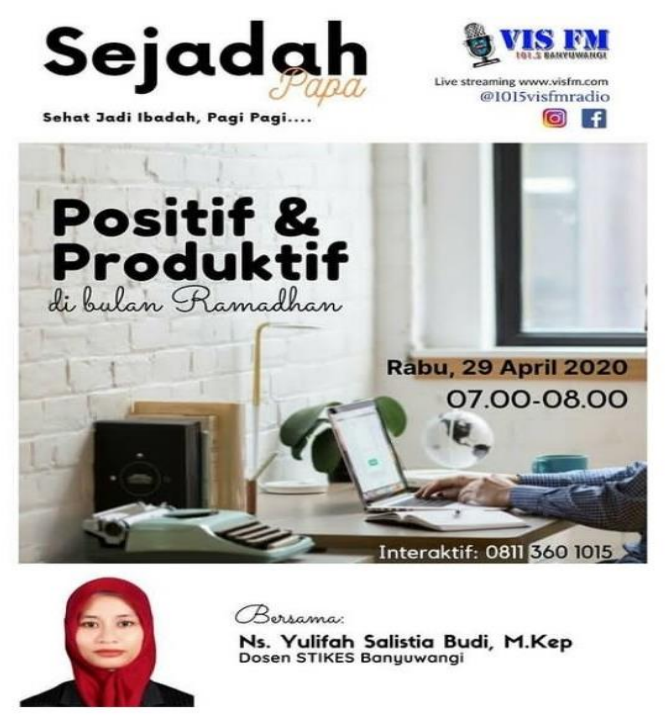

Gambar 1. Poster kegiatan

Berpikir positif pada individu dapat dilakukan dengan memikirkan hal-hal yang prioritas serta berada di waktu yang dekat, menyusun kerangka berpikir dengan mencari sumber yang akurat dari sumber yang terpercaya, menghormati dan menghargai apa yang sedang dan yang mungkin dilakukan oleh orang lain yang berkaitan dengan pandemi Covid-19 serta selalu bersyukur atas anugerah dari Tuhan YME dengan cara meningkatkan kualitas ibadah seseorang. Kemudian untuk kegiatan - kegiatan produktif yang dapat dan tetap bisa dilakukan pada masa pandemi Covid-19 ini adalah membuat daftar kegiatan yang terstruktur sesuai dengan prioritas, tetap membuat aktivitas me time untuk menjaga kondisi jiwa untuk tetap sehat sehingga tidak jenuh dengan rutinitas yang "dirumah saja", melakukan olahraga yang dapat dilakukan di rumah, selalu dan tetap menjalin komunikasi dengan rekan, tetangga, keluarga dan saudara meskipun dengan cara yang virtual misalnya melalui WhatsApp, telepon, media online dan sebagainya untuk 
756 Upaya Pengendalian Kecemasan Masyarakat dengan Tetap Positif dan Produktif di Masa Pandemi Covid-19 - Yulifah Salistia Budi

DOI: https://doi.org/10.31004/abdidas.v2i4.360

mengetahui kabar dan aktivitas serta diskusi dengan mereka serta melakukan upgrade diri dengan cara melakukan atau mencoba kegiatan yang belum pernah seseorang tersebut lakukan melalui metode trial-error selama kegiatan tersebut tidak merugikan diri dan orang lain.

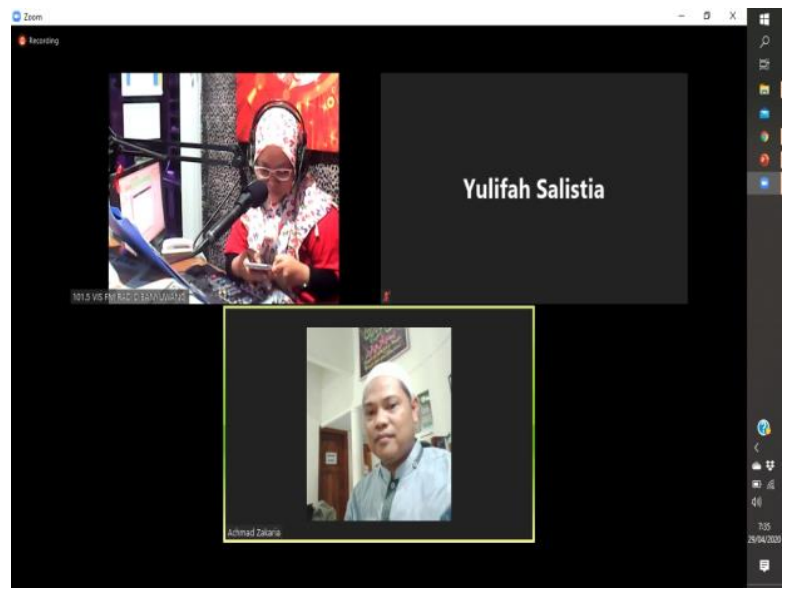

Gambar 2. Kegiatan Edukasi

Hasil pengabdian masyarakat ini berjalan lancar, disampaikan secara langsung melalui siaran radio dan live streaming kepada masyarakat Banyuwangi dan dilanjutkan dengan sesi tanya jawab dan diskusi dari pendengar. Kegiatan tanya jawab dan diskusi antara narasumber dengan pendengar/audience bertujuan untuk mengevaluasi tingkat pemahaman audience terhadap kiat pengendalian kecemasan dengan cara berpikir positif yang diintegrasikan dengan nilai Islami serta perilaku-perilaku produktif selama masa pandemi Covid-19. Hasil evaluasi kegiatan ini menunjukkan bahwa tingkat pemahaman masyarakat meningkat terkait Covid-19, untuk tetap berpikir positif dan produktif meskipun dirumah saja sebagai upaya pengendalian kecemasan yang dialami oleh masyarakat akibat dari pandemi Covid-19. Motivasi masyarakat untuk tetap bersyukur, lebih mendekatkan diri kepada Tuhan nya serta beraktivitas di rumah saja pun juga meningkat tampak dari antuasias penanya kepada masing-masing narasumber.

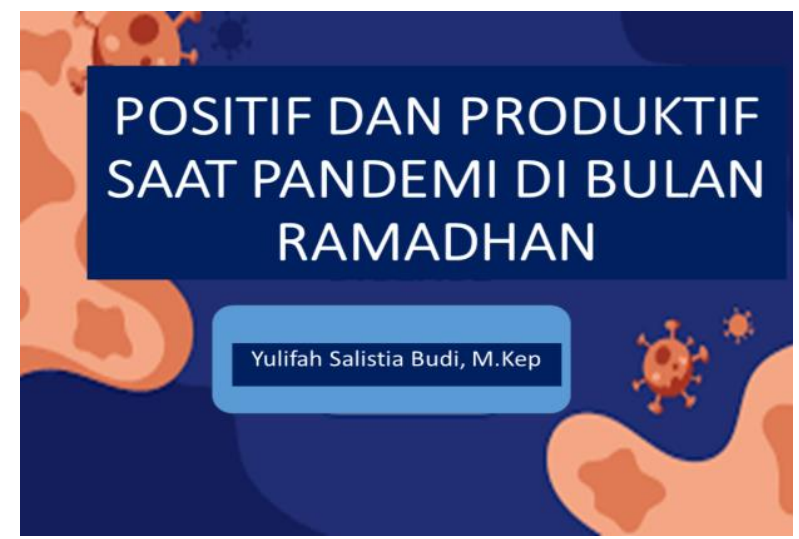

Gambar 3. Tampilan Presentasi

\section{SIMPULAN}

Covid-19 memberikan dampak dari segala segi kehidupan termasuk dalam hal kesehatan jiwa yaitu kecemasan yang dialami masyarakat. Regulasi pemerintah untuk tetap dirumah saja merupakan salah satu faktor pencetusnya, hal ini dapat dikendalikan dengan upaya menggunakan strategi koping berfokus pada masalah yaitu dengan cara untuk tetap berpikir positif dan produktif meskipun di rumah saja. Dengan upaya ini dinilai dapat mengendalikan kecemasan masyarakat pada umumnya dan Banyuwangi khususnya.

\section{UCAPAN TERIMA KASIH}

Penulis menyampaikan terimakasih kepada STIKES Banyuwangi dan Radio VIS FM yang telah memberikan kesempatan dan mengijinkan kami untuk melakukan edukasi upaya 
757 Upaya Pengendalian Kecemasan Masyarakat dengan Tetap Positif dan Produktif di Masa Pandemi Covid-19 - Yulifah Salistia Budi

DOI: https://doi.org/10.31004/abdidas.v2i4.360

pengendalian kecemasan untuk tetap berpikir positif dan produktif selama pandemi covid-19 kepada masyarakat Banyuwangi.

\section{DAFTAR PUSTAKA}

Ishak, M., \& Mangundjaya, W. L. (2020). Pengelolaan stres dan peningkatan produktivitas kerja selama work from home pada masa pandemi covid-19. Jurnal Psikologi Udayana, 7(2), 93-109. https://doi.org/10.24843/JPU.2020.v07.i02.p. 09

Jannah, R. J., Jatimi, A., Azizah, M. J., Munir, Z., \& Rahman, H. F. (2020). Kecemasan Pasien COVID-19: A Systematic Review. Jurnal Penelitian Kesehatan Suara Forikes, 11(2), 33-37.

Kementrian Kesehatan Republik Indonesia. (2020). Pedoman Pencegahan dan Pengendalian Coronavirus Disease (Covid19).

https://covid19.go.id/storage/app/media/Proto kol/REV05_Pedoman_P2_COVID-

19_13_Juli_2020.pdf, pada 3 November 2020

Kertamuda, F., \& Herdiansyah, H. (2009). Pengaruh Strategi Coping terhadap Penyesuaian Diri Mahasiswa Baru. Jurnal Universitas Paramadina, 6(1), 11-23.

Kusumastiwi, T. (2020). Positif dan Produktif Saat Pandemi. Universitas Muhammadiyah Yogyakarta.

Megatsari, H., Laksono, A. D., Ibad, M., Herwanto, Y. T., Sarweni, K. P., Geno, R. A. P., \& Nugraheni, E. (2020). The community psychosocial burden during the COVID-19 pandemic in Indonesia. Heliyon, 6(10), $\mathrm{e} 05136$.

https://doi.org/10.1016/j.heliyon.2020.e0513 6

Pratama, A. M. (2020). Tips Menkes Cegah Virus Corona: Berpikiran Positif dan Jaga Imunitas.

https://money.kompas.com/read/2020/01/27/ 155000326/tips-menkes-cegah-virus-coronaberpikiran-positif-dan-jaga-imunitas, pada 27 Januari 2020
Rohmatussyifa, Z., \& Sa'id, M. (2020). Bias Optimisme 'Berpikir Positif' Di Masa Pandemi Covid-19. Buletin KPIN, 6(12).

Salistia Budi, Y. (2021). Aspek Kecemasan Saat Menghadapi Ujian dan Bagaimana Strategi Pemecahannya (F. A. Rahmawati (ed.)). Jakad Media. 